\title{
Persepsi dan Sikap Guru tentang Pendayagunaan Media Jaringan Sosial dalam Pembelajaran Tingkat SLTA di Timor Leste
}

\author{
Ali Gunawan ${ }^{1}$ dan Agostinho de Fatima ${ }^{2}$ \\ ${ }^{1,2}$ Information Systems Department, School of Information Systems, Bina Nusantara \\ University, Jakarta, Indonesia 11480 \\ *Email: gunlee77@gmail.com
}

\begin{abstract}
Di Timor Leste salah satu fenomena yang saat ini sedang ramai diperbincangkan adalah tentang berkembangnya media jaringan sosial. Media tersebut kini menjadi trend di seluruh kalangan masyarakat di Timor Leste tanpa memandang usia, hal itu dikarenakan media jaringan sosial memberikan kemudahan layanan dalam berkomunikasi, khususnya berinteraksi dan berbagi informasi antar manusia. Jika dikaitkan dalam konteks pendidikan, maka media jaringan sosial menjadi salah satu sarana komunikasi yang dapat dimanfaatkan dalam proses manajemen pendidikan dan pembelajaran bagi guru di Timor Leste. Pemanfaatan media tersebut tentu memiliki dampak positif dan negatif yang dapat memengaruhi keberhasilan lembaga pendidikan dalam mencapai tujuan.
\end{abstract}

\begin{abstract}
One of the phenomena in the 20th century that is currently being discussed is about emerging and the development of many social networking media. The media is now a trend all over among the people regardless of age, it is because social networking media provides convenience services in communicating, interact and share information between human. If associated in the context of education, then social networking media to be one of the means of communication that can be utilized in the process of education management and learning for teachers.
\end{abstract}

Kata Kunci: Social networking media; communication; educational management; learning; media jejaring sosial; komunikasi; manajemen pendidikan; pembelajaran.

\section{Pendahuluan}

Saat ini perkembangan Ilmu Pengetahuan dan Teknologi (IPTEK) semakin pesat dan telah dirasakan oleh berbagai pihak yang menggunakan serta memanfaatkannya. Perkembangan tersebut berupa munculnya berbagai inovasi-inovasi baru mengenai teknologi yang membantu manusia dalam menyelesaikan pekerjaan, membantu komunikasi antar manusia, dan membantu manusia mengembangkan ilmu pengetahuan itu sendiri. Selain itu, IPTEK juga berperan besar dalam membentuk manusia di era yang akan datang. Hal tersebut mencakup berbagai bidang, tak terkecuali dalam bidang pendidikan. Sebagai salah satu bidang yang bertujuan mengembangkan kemampuan diri manusia dan memberikan nilai-nilai budi pekerti, pendidikan juga berperan penting dalam memantau perkembangan IPTEK di era kini dan yang akan datang. Sekolah menjadi sarana yang tepat dalam mengembangkan segala potensi yang dimiliki seluruh masyarakat untuk lebih ditingkatkan dan dimanfaatkan kembali ke lingkungannya.

Disisi lain, jika melihat perkembangan teknologi saat ini, terdapat berbagai terobosan dan inovasi dalam mempermudah proses kerja dan kehidupan sehari-hari. Salah satu fenomena yang saat ini sedang ramai diperbincangkan adalah tentang media jaringan sosial. Media tersebut kini menjadi trend di seluruh kalangan masyarakat tanpa memandang usia, hal itu karena media jaringan sosial memberikan 
kemudahan dalam berkomunikasi khususnya berinteraksi dan berbagi informasi kepada seluruh manusia. Jika dikaitkan dalam kajian pendidikan, media jaringan sosial juga menjadi salah satu kebutuhan dalam komunikasi sehari-hari dalam pelaksanaan pendidikan. Namun, hal tersebut tidak lantas menjadi hal yang selalu berdampak positif bagi proses pendidikan, banyak hal negatif pula yang menjadi dampak digunakannya media jaringanan sosial tersebut. Salah satu dampak negatif adanya media tersebut adalah timbulnya suatu kebiasaan dari pengguna ketika memanfaatkan media jaringan sosial tanpa mengenal waktu dan kondisi khususnya dalam lingkungan sekolah, hal tersebut yang akan memengaruhi terhambatnya keberhasilan dari sekolah dalam mewujudkan tujuan pendidikan.

Setidaknya terdapat dua faktor yang dapat mewujudkan keberhasilan sekolah, khususnya dalam membentuk manusia yang siap menghadapi era yang akan datang, yakni faktor manajemen sekolah dan pembelajaran yang efektif. Manajemen sekolah yang efektif tentunya melalui kontribusi yang maksimal dari para warga sekolah dalam merencanakan, mengorganisasikan, melaksanakan, mengawasi pelaksanaan, dan mengevaluasi secara keseluruhan proses manajemen sekolah tersebut. Keseluruhan proses tersebut tentu perlu adanya komunikasi yang baik antara perencana yaitu administrator sekolah (kepala sekolah, wakil, dan para staf) dengan para pelaksana dan pengguna layanan pendidikan yaitu pendidik dan peserta didik. Sementara itu, pembelajaran yang efektif juga melalui kontribusi yang maksimal antara guru sebagai fasilitator belajar dan peserta didik sebagai pembelajar di sekolah, adapun proses yang harus disepakati melalui komunikasi yang baik antara pendidik dan peserta didik meliputi perencanaan pembelajaran berupa materi dan jadwal yang akan diberikan, pelaksanaan pembelajaran berupa pemberian materi serta tugas-tugas terstruktur yang akan diberikan, dan evaluasi pembelajaran berupa proses penilaian pendidik terhadap kemampuan dan potensi yang telah dikembangkan oleh peserta didik. Berdasarkan hal tersebut, proses pendidikan dikatakan efektif jika ada komunikasi yang baik antar warga sekolah dalam menjalankan proses pendidikan, sehingga tujuan pendidikan untuk mengembangkan potensi dan kemampuan peserta didik untuk mengantisipasi perkembangan dan persaingan global akan berjalan dengan optimal melalui manajemen dan pembelajaran yang efektif.

\section{Metode}

Metode penelitian yang digunakan ialah kuantitatif deskriptif. Penelitian ini mengungkap dua macam kelompok variabel sebagai dasar acuan penelitian. Kelompok pertama variabel bebas (X) adalah persepsi tentang media jaringan sosial dengan variabel terikat (Y) sikap terhadap pendayagunaan media jaringan sosial untuk pembelajaran. Sedangkan rumus populasi dalam penelitian ini sejumlah 407 guru, berdasarkan jumlah keseluruhan sekolah yaitu 115 sekolah, akan ditentukan jumlah sampel sekolah sebesar $10 \%$ dari jumlah keseluruhan sekolah. Penentuan 10\% sekolah tersebut berdasarkan pendapat Sugiarto, dkk (2003:10) yang menyatakan, bahwa "pada umumnya untuk tahap awal ataupun untuk peneliti pemula, sampel diambil sekitar 10 persen dari total individu populasi yang diteliti", sehingga ditentukan jumlah sekolah yang menjadi sampel sejumlah 12 sekolah. Kemudian untuk pengambilan sampel responden menggunakan teknik proportional simple random sampling dan menggunakan rumus formula Slovin (Setyadin, 2005:20), diperoleh hasil sampling sejumlah 202 guru. Penelitian ini menggunakan data kuantitatif jenis data ordinal (persepsi dan sikap), untuk pengumpulan data dalam penelitian ini menggunakan angket atau kuesioner tertutup. Teknik analisis data dalam penelitian ini menggunakan rumus analisis deskriptif yaitu menentukan kualifikasi, nilai tengah, dan menentukan persentase (Wiyono dalam Burhanuddin, 2007:68).

\section{Hasil}

Deskripsi variabel penelitian yang akan disajikan terlebih dahulu diuji dengan rumus-rumus yang telah ditentukan, serta dengan bantuan program Method of Successive Interval (MSI) dan Statistical Product and Service Solution (SPSS) 16.0 for windows. Ringkasan analisis deskriptif variabel penelitian disajikan pada tabel 1 . 
Tabel 1. Hasil Analisis Deskriptif Variabel Persepsi dan Sikap

\begin{tabular}{ccc}
\hline Variabel & Persepsi & Sikap \\
\cline { 1 - 2 } Parameter & & \\
\hline Mean & 105,08696 & 54,32355 \\
\hline Standar Deviasi & 12,84094 & 7,39780 \\
\hline Varians & 164,88972 & 54,72744 \\
\hline Kurtosis & 1,72844 & 0,57086 \\
\hline Skewness & 0,01937 & $-0,05143$ \\
\hline Skor Min & 54,64747 & 29,40125 \\
\hline Skor Max & 151,17290 & 75,21198 \\
\hline Range & 96,52542 & 45,81073 \\
\hline Sum & 21227,56557 & 10973,35758 \\
\hline N (Sampel) & 202 & 202 \\
\hline Peluang Max & 153,46603 & 79,40640 \\
\hline Peluang Min & 30,00000 & 15,00000 \\
\hline Range Peluang & 123,46603 & 64,40640 \\
\hline Interval & 41,15534 & 21,46880 \\
\hline Kategori Rendah & $\leq 71,15533$ & $\leq 36,46879$ \\
\hline Kategori Sedang & $\leq 112,31068$ & $\leq 57,93759$ \\
\hline Kategori Tinggi & $\geq 112,31068$ & $\geq 57,93759$ \\
\hline & &
\end{tabular}

\section{Persepsi Guru}

Variabel persepsi guru memiliki sub-variabel, antara lain (1) faktor penilai/diri guru, (2) faktor situasi/lingkungan guru, dan (3) faktor target/kualitas media jaringanan sosial. Sub-variabel tersebut dijabarkan menjadi indikator-indikator pernyataan yang berjumlah 30 butir. Analisis pada variabel persepsi, yaitu dengan menentukan kualifikasi yang bertujuan untuk mengetahui interval nilai masingmasing variabel yang terdiri atas tingkat rendah, sedang, dan tinggi. Penentuan tersebut menggunakan rumus 3.4 , berikut perhitungannya:

$$
\begin{gathered}
\text { Panjang Kelas Interval }=\frac{\text { Rentang }}{\text { Banyak Kelas }} \\
\text { Panjang Kelas Interval }=\frac{153,46603-30,00000}{3,00000}=\frac{123,46603}{3,00000}=41,15534
\end{gathered}
$$

Berdasarkan perhitungan di atas terdapat peluang skor tertinggi 153,46603 dikurangi peluang skor terendah 30,00000 memeroleh hasil peluang range 123,46603, yang kemudian dibagi tiga kategori dan diperoleh panjang kelas interval, yaitu 41,15534. Dengan mengetahui hasil tersebut, diperoleh pula kategori tinggi, yaitu $\geq 112,31068$; kategori sedang, yaitu $\leq 112,31068$; dan kategori rendah, yaitu $\leq$ 71,15533. Diketahuinya kategori tertinggi hingga terendah tersebut akan dijadikan kriteria kategori dalam variabel persepsi. Hasil analisis deskriptif menunjukkan persepsi guru tentang pendayagunaan media jaringan sosial dalam pembelajaran tingkat SLTA di Timor Leste dalam kategori 'sedang', yaitu dengan angka rata-rata/mean 105,08696 $\leq 112,31068$.

\section{Sikap Guru}


Variabel sikap guru memiliki sub-variabel, antara lain (1) aspek kognitif, (2) aspek afektif, dan (3) aspek konatif. Subvariabel tersebut dijabarkan menjadi indikator-indikator pernyataan yang berjumlah 15 butir. Analisis pada variabel sikap, yaitu dengan menentukan kualifikasi yang bertujuan untuk mengetahui interval nilai masing-masing variabel yang terdiri atas tingkat rendah, sedang, dan tinggi. Penentuan tersebut menggunakan rumus 3.4 , berikut perhitungannya:

$$
\begin{gathered}
\text { Panjang Kelas Interval }=\frac{\text { Rentang }}{\text { Banyak Kelas }} \\
\text { Panjang Kelas Interval }=\frac{79,40640-15,00000}{3,00000}=\frac{64,40640}{3,00000}=21,46880
\end{gathered}
$$

Berdasarkan perhitungan di atas terdapat peluang skor tertinggi 79,40640 dikurangi peluang skor terendah 15,00000 memeroleh hasil peluang range 64,40640, yang kemudian dibagi tiga kategori dan diperoleh panjang kelas interval, yaitu 21,46880. Dengan mengetahui hasil tersebut, diperoleh pula kategori tinggi, yaitu $\geq 57,93759$; kategori sedang, yaitu $\leq 57,93759$; dan kategori rendah, yaitu $\leq$ 36,46879. Diketahuinya kategori tertinggi hingga terendah tersebut akan dijadikan kriteria kategori dalam variabel sikap. Hasil analisis deskriptif menunjukkan sikap guru tentang pendayagunaan media jaringan sosial dalam pembelajaran tingkat SLTA di Timor Leste termasuk dalam kategori 'sedang', yaitu dengan angka rata-rata/mean 54,32355 $\leq 57,93759$.

\section{Pembahasan}

\section{Persepsi Guru}

Berdasarkan hasil analisis pada bab sebelumnya, menunjukkan persepsi guru tingkat SLTAdi Timor Leste pada kategori 'sedang'. Hal tersebut dapat dibuktikan pada hasil nilai mean, frekuensi \& persentase variabel, dan frekuensi \& persentase subvariabel yang sama menunjukkan kategori 'sedang'. Adapun hasil mean 105,08696 $\leq 112,31068$, sedangkan nilai frekuensi \& persentase variabel menunjukkan $71,8 \%$ atau sebanyak 145 guru memahami beberapa faktor yang meliputi fungsi, manfaat dan resiko media jaringan sosial dalam pembelajaran. Hal tersebut diperkuat dengan hasil frekuensi \& persentase berdasarkan subvariabel, dengan nilai tertinggi pada sub-variabel faktor penilai/diri guru yaitu 73,3\% atau sebanyak 146 guru mempertimbangkan pengetahuan yang dialami dan dipahami oleh dirinya tentang media jaringan sosial yang sehingga menjadi faktor paling utama dalam proses ini. Selain itu, diikuti faktor situasi/lingkungan guru sejumlah 66,8\% (135 guru), dan faktor target/kualitas media jaringan sosial sejumlah 64,4\% (130 guru).

Salah satu elemen dalam faktor penilai/diri guru yang dapat memengaruhi prosesnya memahami media jaringan sosial pada pembelajaran adalah "saya (guru) ingin menggunakan media jaringan sosial untuk membuat komunitas antar guru", pernyataan tersebut terdapat pada instrumen bagian kedua (PG) nomor 7 dengan melihat nilai mean dan berdasarkan kriteria nilai per butir instrumen. Hal tersebut sejalan dengan pendapat Robbins \& Judge (2015) yang menjelaskan pembentukan teori persepsi dipengaruhi oleh berbagai faktor, salah satunya faktor penilai yang terdiri atas sikap, motif, minat, pengalaman, dan ekspektasi.

Selain itu, didukung dengan pendapat Kietzmann, dkk (2011) dengan bagan 'sarang lebah' yang memaparkan bahwa terdapat salah satu fungsi media jaringan sosial yaitu sejauh mana pengguna membentuk komunitas dalam media jaringan sosial. Hal tersebut dapat diinterpretasikan bahwa proses pemahaman/persepsi guru tentang media jaringan sosial dalam pembelajaran tingkat SLTA di Timor LEste ditentukan oleh faktor penilai/diri guru pribadi, dengan guru mengetahui segala fungsi, manfaat, 
dan resiko media jaringan sosial dalam pembelajaran serta mengetahui motif dalam menggunakan media jaringan sosial, salah satunya yaitu membentuk komunitas guru.

\section{Sikap Guru}

Melihat hasil analisis pada bab sebelumnya, menunjukkan sikap guru tingkat SLTA di Timor Leste pada kategori 'sedang'. Hal tersebut dapat dibuktikan pada hasil nilai mean, frekuensi \& persentase variabel, dan frekuensi \& persentase sub-variabel yang sama menunjukkan kategori 'sedang'. Adapun hasil mean $54,32355 \leq 57,93759$, sedangkan nilai frekuensi \& persentase variabel menunjukkan $70,3 \%$ atau sebanyak 142 guru telah atau akan menerima/mengadopsi media jaringan sosial sebagai media komunikasi dalam pembelajaran. Hal tersebut diperkuat dengan hasil frekuensi \& persentase berdasarkan sub-variabel, dengan nilai tertinggi pada sub-variabel aspek afektif yaitu $68,3 \%$ atau sebanyak 138 guru mempertimbangkan aspek afektif atau perilaku dalam menggunakan media jaringan sosial, hal tersebut menjadi aspek paling utama dalam proses menerima/adopsi media jaringan sosial dalam pembelajaran. Selain itu, diikuti aspek konatif sejumlah 65,8\% (133 guru), dan aspek kognitif sejumlah $60,3 \%$ (122 guru).

Salah satu faktor dalam aspek afektif yang dapat memengaruhi seorang guru dalam proses menerima/adopsi media jaringan sosial pada pembelajaran adalah "memanfaatkan media jaringan sosial dalam pembelajaran merupakan hak dari setiap guru", pernyataan tersebut terdapat pada instrumen bagian ketiga (SG) nomor 6 dengan melihat nilai mean dan berdasarkan kriteria nilai per butir instrumen. Hal tersebut sejalan dengan pendapat Robbins \& Judge (2015) yang menjelaskan salah satu komponen/aspek sikap, yaitu "komponen afektif yaitu segmen perasaan atau emosional dari suatu sikap". Selain itu diperkuat dengan beberapa manfaat media jaringan sosial dalam pembelajaran menurut Blazer (2012) meliputi “(1) memungkinkan para guru untuk dengan cepat mengenali kebutuhan belajar peserta didik; (2) menyediakan alat bagi guru untuk mengajarkan peserta didik bertanggung jawab dalam bersosial; (3) menciptakan komunitas belajar yang profesional bagi guru". Oleh karena itu, dapat diinterpretasikan bahwa proses menerima/adopsi media jaringan sosial oleh guru tingkat SLTA di Timor Leste ditentukan pada aspek afektifnya, dengan guru terlebih dahulu mengetahui manfaat dan resiko media jaringan sosial yang kemudian dikaitkan dengan cara penggunaan yaitu mengacu pada halhal yang positif dalam mengakses media tersebut sehingga dapat mengontrol segala resiko dan tanggapan yang memengaruhi emosional/perasaan guru ketika menggunakan media jaringan sosial tersebut.

\section{Simpulan}

Berdasarkan hasil penelitian dan pembahasan temuan penelitian, dapat diperoleh kesimpulan sebagai berikut. Pertama, persepsi guru tentang pendayagunaan media jaringan sosial untuk pembelajaran tingkat SLTA di Timor Leste berada dalam kategori sedang. Kedua, sikap guru tentang pendayagunaan media jaringan sosial untuk pembelajaran tingkat SLTA di Timor Leste berada dalam kategori sedang.

\section{Saran}

Adapun saran-saran yang sesuai dengan hasil penelitian dan beberapa temuan pada penelitian ini. Pertama, bagi Kepala Dinas Pendidikan dan Kementerian pendidikan Timor Leste. Diketahuinya persepsi, sikap, inovasi, dan difusi guru yang sedang tentang media jaringan sosial dalam pemanfaatannya untuk pembelajaran. Diharapkan pihak Dinas Pendidikan dan Kementerian pendidikan mempertimbangkan penerbitan regulasi tentang pemanfaatan media jaringan sosial sebagai media komunikasi alternatif dalam pembelajaran guna meningkatkan kemampuan menghadapi teknologi yang berkembang semakin pesat. Disamping itu, perlu memberikan fasilitas pendukung berupa akses jaringan wi-fi dengan kecepatan tinggi di setiap sekolah guna mendukung pemanfaatan media jaringan sosial tersebut. 
Kedua, bagi Dinas Komunikasi dan Informasi Timor Leste. Dinas Komunikasi dan Informatika Timor Leste selaku instansi yang dapat memberikan layanan dan fasilitas mengenai hal komunikasi kepada publik, hendaklah mempertimbangkan kajian ini untuk memberikan layanan berupa pembuatan media jaringan sosial khusus untuk dimanfaatkan sebagai media pembelajaran alternatif bagi guru dan peserta didik. Selain itu, juga melakukan pengawasan terhadap berbagai macam media jaringan sosial berupa upaya pemblokiran situs atau konten yang berbau penghinaan dan penyalahgunaan media baik berupa audio maupun visual terhadap Suku, Agama, Ras, dan Antar golongan (SARA) sehingga media jaringan sosial dapat dialihkan sebagai media alternatif untuk pembelajaran yang lebih menarik sesuai dengan fungsinya.

Ketiga, bagi seluruh Kepala tingkat SLTA di Timor Leste. Kepala Sekolah selaku manajer dan administrator sekaligus supervisor sekolah hendaknya mempertimbangkan dan memberikan wawasan mengenai pemanfaatan internet kepada guru maupun peserta didik, khususnya media jaringan sosial yang telah ada untuk dimanfaatkan sebagai media komunikasi alternatif dalam pembelajaran. Selain hal tersebut, juga hendaklah meningkatkan fasilitas berupa kecepatan akses internet yang lebih maksimal di lingkungan sekolah, agar tujuan pemanfaatan media jaringan sosial dalam pembelajaran dapat terdukung dan terwujud dengan baik.

Keempat, bagi seluruh guru tingkat SLTA di Timor Leste. Guru sebagai pemodelan ideal bagi peseta didik dan orang yang secara langsung bertatap muka dengan peserta didik, dapat mempertimbangkan untuk memberi wawasan kepada peserta didik agar dapat memanfaatkan media jaringan sosial yang telah ada, dalam proses belajar mengajar sebagai media komunikasi alternatif dalam pembelajaran. Selain itu, juga memberikan inovasi metode mengajar di kelas dengan memberikan tugas atau mencoba bertatap muka di dunia maya sehingga peserta didik tidak merasa bosan dengan pembelajaran bertatap muka langsung di kelas. Hal terpenting lainnya yaitu, guru hendaklah dapat menjadi kontrol moral dan etika peserta didik dalam pemanfaatan media jaringan sosial, sehingga kemungkinan kegiatan yang mengarah pada hal negatif dapat dicegah dan tidak terjadi.

Kelima, bagi peneliti lain. Peneliti lain dapat mengembangkan hasil penelitian ini dengan meneliti pada objek penelitian lainnya, yaitu dari sisi kepala sekolah sebagai pemimpin, manajer, dan supervisor. Alasannya bahwa mereka memiliki wewenang untuk membuat kebijakan-kebijakan manajemen pendidikan. Tentu saja harus dapat diterapkan terhadap variabel dan lokasi penelitian yang lain, baik pada jenjang Sekolah Lanjutan Tingkat Pertama (SLTP) maupun perguruan tinggi. Penelitian yang dilakukan dengan model dan fokus baru yakni model pemanfaatan media jaringan sosial dalam rangka peningkatan efektivitas pembelajaran.

\section{Daftar Rujukan}

Blazer, C. 2012. Social Networking in Schools: Benefits and Risk; Review of the Research; Policy Considerations; and Current Practices. Research Services, 1109:1—23.

Kietzmann, J.H., Hermkens, K., McCarthy, I.P \& Silvestre, B.S. 2011. Social Media? Get Serious! Understanding The Functional Building Blocks of Social Media. Business Horizons, 54:241— 251.

Robbins, S.P \& Judge, T.A. 2015. Organizational Behavior (Edisi 16) (Saraswati. R \& Sirait. F, Ed). Jakarta: Penerbit Salemba Empat.

Setyadin, B. 2005. Modul IV: Desain dan Metode Penelitian Kuantitatif. Malang: Lembaga Penelitian Universitas Negeri Malang.

Sugiarto., Siagian, D., Sunaryanto, L.T. \& Oetomo, D. 2003. Teknik Sampling. Jakarta: PT. Sun. 
Wiyono, B.B. 2007. Metodologi Penelitian: Pendekatan Kuantitatif, Kualitatif, dan Action Research. Malang: Rosindo 